\title{
ISOLATION AND IDENTIFICATION OF STREPTOCOCCUS EQUI SUBSPECIES EQUI FROM EQUINE WHICH SUFFER FROM STRANGLES
}

\section{Talat Hamed Sheashe Badier}

Senior Researchers Microbiological Vet. Lab., Animal Health Institute

\begin{abstract}
400 swabs were collected from 200 horses (100 apparently healthy and 100 diseased ones) and 200 donkeys (100 apparently healthy and 100 diseased ones). These samples were taken from abscess at lymph nodes, nose and rectum of equine animals.
\end{abstract}

The incidence of Strept. equi sub. sp. equi was 52 (26\%) in 200 horses and $32(16 \%)$ in 200 donkeys. This incidence of this microorganisms was 25 (12.5\%) and 20 (10\%) in diseased horses and donkey, respectively while, in an apparently healthy ones, it was 27 (13.5\%) and $12(6 \%)$ in horses and donkey respectively.

The rate of isolation of Strept. equi sub. sp. equi was 27 (51.92\%) and 12 (37.5\%) in apparently healthy horses and donkey while, in diseased ones, it was 25 (48.8\%) and 20 (62.5\%) in horses and donkeys respectively.

The isolates of Strept. equi sub. sp. equi were sensitive to ampicillin, with activity percent (95.24\%) then to tetracycline (83.33\%), streptomycin (83.33\%) and gentamycin (83.33\%), on other hand they were less sensitive to erythromycin (35.91\%), kanamycin (41.67\%) and lincomycin (35.71\%). 


\section{INTRODUCTION}

Streptococcus infections is considered as one of the most infectious disease in an equine including a wide range of infection (pneumonia, endocarditis, meningitis, septic arthritis and lymphadenitis),(Spoormakers et al., 2003 and Goethining et al., 2005).

Strangles is an important streptococcal disease in all countries where horses and donkeys are kept. It is an acute disease of young animals. The main cause of the disease is Streptococcus equi sub sp. equi (Gronback et al., 2006).

Equine had a greet value due to its working ability and other value. The animals were susceptible to infection with microorganism which cause respiratory manifestations. Strangles is one of the most important and common diseases of equines. It is caused by Streptococcus equi sub sp. equi which infect the upper respiratory tracts with abscessation of adjacent behined mandiboler lymph nodes(Daulat et al.,2001 and Farag, A.N. and Dapgh A.M., 2006).

This study was done to isolate Streptococcus equi sub species equi from equin animals and detect its incidence among apparently healthy and diseases ones and also detect its sensitivity pattern to various antimicrobial agents.

\section{MATERIAL AND METHODS}

\section{Animals:}

\section{a) Field animals:}

A total of 200 horses 100 out of them showing signs suspected to be strangles and the remaining were apparently healthy. In addition 200 monkeys 100 out of them were showing signs suspected to be strangles and the remaining were apparently healthy. All animals in this study were aged 2-5 years. 
Those animals were examined both clinically and bacteriologically against strangles during the period January 2006 to December 2008 as shown by Table (1).

\section{b. Laboratory animals:}

White mices (50-60 g wt).

\section{Samples:}

a. Deep nasal swabs.

b. Rectal swabs.

c. Aspiration from abssecated lymph nodes.

\section{Samples collection:}

Deep nasal and rectal swabs were collected from 100 apparently health horses which reared alone and with other large domestic farm animals and also 100 apparently healthy donkeys which reared alone and with other domestic large farm animals.

Deep nasal, abscess, and rectal swabs were collected from horses and donkey (either healthy or diseased ones).

Two hundred samples were collected from 200 diseased animals (100 horses and 100 donkeys), they included swabs from abscesses, deep nasal and rectum. All collected samples were put in an ice box and transferred immediately to laboratory for bacterial examination. All animals in this study were aged 2-5 years.

\section{Media:}

\section{A. Fluid media:}

- Nutrient broth (Bailey and Scott, 1974).

- Sugar media for fermentation (Cruickshank et al., 1975). 


\section{B. Solid media.}

a. Ewdard's medium (Solytus, 1963).

b. 10\% blood agar (Cruickshank et al., 1975).

c. Muller hinton agar (Oxoid, co.), It is shown by Bailey and Scott, 1974).

\section{Chemical and solutions:}

- Peptone water.

- Hydrogen peroxide (110 volume 30-31\%).

- $\mathrm{HCl}$ solutions ( $10 \%$ and $1 / 2$ liter).

- $\mathrm{NaOH}(1 \mathrm{~N}$ and $0.5 \mathrm{~N})$.

- Four molar solution of sodium nitrate.

- Glacial acetic acid.

- Normal saline $0.85 \%$.

- $1 \%$ phenol red solution as $\mathrm{pH}$ indicator.

\section{Isolation and identification:}

1. Smears from samples were stained with gram's method, then microscopically examined.

2. Direct cultivation of collected swabs on modified Edward's medium as selective medium for Strept. equi sub species equi and on blood agar medium and aerobically incubation at $37^{\circ} \mathrm{C}$ for $24-48$ hours.

3. The growing colonies were identified on blood agar according to the type of haemolysis. 
4. Subspected colonies on modified Edward's medium were identified morphologically and biochemically criteria.

5. Pathogenicity tests for the suspected colonies were done according to Cayeux and Panijel (1965).

6. Suspected colonies were identified serologically by commercially available lancefied grouping system kits (Laex agglutination) for streptococcus identification (Oxoid U.K.).

7. Sensitivity test of the suspected colonies to antimicrobial agents by using disc diffusion method according to Balilly and Scott (1974), Finegold and Martin (1982) which are shown in Table (2).

Table (1): Type and number collected from apparently and affected horses and donkeys.

\begin{tabular}{|c|c|c|c|c|c|}
\hline \multirow{2}{*}{ Type swabs } & \multicolumn{4}{|c|}{ Number of species animals } & \multirow{2}{*}{ Total } \\
\hline & \multicolumn{2}{|c|}{ Apparently healthy } & \multicolumn{2}{|c|}{ Diseased } & \\
\hline Abscesses & 0 & 0 & 50 & 50 & 100 \\
\hline Deepnose & 50 & 50 & 25 & 25 & 150 \\
\hline Rectum & 50 & 50 & 25 & 25 & 150 \\
\hline Total & 100 & 100 & 100 & 100 & 400 \\
\hline
\end{tabular}

Table (2): Types and amount/disk for antimicrobial agents disk used.

\begin{tabular}{|l||c||c|}
\hline \multicolumn{1}{|c||}{ Type } & \multicolumn{2}{|c||}{ Amount/disk code number difico } \\
\hline \hline Ampicilin & $10 \mathrm{mcg}$ & $6363-33.9$ \\
Erythromycin & $15 \mathrm{mcg}$ & $6153-33.3$ \\
Gentamycin & $10 \mathrm{mcg}$ & $6423-33.7$ \\
Kanamycin & $30 \mathrm{mcg}$ & $6263-33.0$ \\
Lincomycin & $2 \mathrm{mcg}$ & $6381-3.7$ \\
Streptomycin & $10 \mathrm{mcg}$ & $6203-33.3$ \\
Tetracyclin & $30 \mathrm{mcg}$ & $6223-33.9$ \\
\hline
\end{tabular}

Kafrelsheikh Vet. Med. J. Vol. 7 No. 1 (2009) 


\section{RESULTS}

Clinical examination of 400 equine animals (200 horses and 200 donkeys) which were aged 2-5 years, these animals reared in private farms. They include 200 apparently healthy and 200 diseased equine animals. The symptoms of diseased animals were respiratory manifestations showing of fever, anorexia and depression respiratory dysnonia, purulent discharge and swelling of one or both lymph nodes of throat region.

The bacteriological examination of (400) samples collected from apparently and clinically diseased revealed incidence of Streptococcus equi $84(21 \%)$ in table (3), they were $27(13.5 \%)$ and $12(6 \%)$ from apparently healthy horses and donkeys respectively while, in diseased ones, they were $2.5(12.5 \%)$ in horses and 20 (10) in donkeys as shown in Table (4).

Table (3): The incidence of streptococcus species in apparently health and diseased horses and donkeys.

\begin{tabular}{|c||c|c|c|c|}
\hline \multirow{2}{*}{ Animal type \& No. } & \multicolumn{4}{|c|}{ Streptococcus spp. } \\
\cline { 2 - 5 } & No & $\mathbf{\%}$ & Other species \\
\cline { 2 - 5 } & 52 & 26 & 38 & $\%$ \\
\hline \hline Horses (200) & 32 & 16 & 43 & 21.5 \\
Donkeys (200) & $\mathbf{8 4}$ & $\mathbf{2 1}$ & $\mathbf{8 1}$ & $\mathbf{2 0}$ \\
\hline \hline Total (400) &
\end{tabular}

Table (4): Incidence of Strept. equi sub. sp. equi among apparently and diseased equine animals.

\begin{tabular}{|c|c|c|c|c|c|c|c|c|}
\hline \multirow{4}{*}{$\begin{array}{c}\text { Type of } \\
\text { microorganisms }\end{array}$} & \multicolumn{8}{|c|}{ (400) state of animals } \\
\hline & \multicolumn{4}{|c|}{ Horses (200) } & \multicolumn{4}{|c|}{ Donkey (200) } \\
\hline & \multicolumn{2}{|c|}{ Diseased } & \multicolumn{2}{|c|}{ Apparently health } & \multicolumn{2}{|c|}{ Diseased } & \multicolumn{2}{|c|}{ Apparently health } \\
\hline & No & $\%$ & No & $\%$ & No & $\%$ & No & $\%$ \\
\hline Strept. equi sub sp. & 25 & 12.5 & 27 & 13.5 & 20 & 10 & 12 & 6 \\
\hline Other streptococci & 25 & 12.5 & 13 & 6.5 & 30 & 15 & 13 & 6.5 \\
\hline$\overline{~ T o t a l ~(400) ~}$ & $\overline{\mathbf{5 0}}$ & $\overline{1.5}$ & $\overline{40}$ & $\overline{10}$ & $\overline{50}$ & $\overline{12.5}$ & 25 & 6.25 \\
\hline
\end{tabular}

Kafrelsheikh Vet. Med. J. Vol. 7 No. 1 (2009) 
Isolation And Identification Of Streptococcus.

Table (5): *The rate of isolation of strept. equi sub. sp. equi from apparently healthy and diseased equine animals.

\begin{tabular}{|c|c|c|c|c|c|c|}
\hline \multirow{3}{*}{$\begin{array}{c}\text { Type of } \\
\text { microorganisms }\end{array}$} & \multicolumn{2}{|c|}{ Total } & \multicolumn{4}{|c|}{ State of equine animals } \\
\hline & & & \multicolumn{2}{|c|}{ Apparently health } & \multicolumn{2}{|c|}{ Diseased } \\
\hline & No. & $\%$ & No & $\%$ & No & $\%$ \\
\hline Strept. equi sub sp. & 84 & 50.91 & 39 & 46.93 & 45 & 53.57 \\
\hline Other streptococci & 81 & 49 & 26 & 32.10 & 55 & 67.90 \\
\hline Total & 165 & 100 & 65 & 39.39 & 100 & 60.61 \\
\hline
\end{tabular}

* The rate of isolation is the ratio between the number of Strept equi subspecies equi in apparently healthy and diseased animal to total number of streptococcus isolates.

Table (6): The rate of isolation of streptococcus equi sub species equi from apparently and diseased horses and donkeys.

\begin{tabular}{|c|c|c|c|c|c|c|c|c|}
\hline \multirow{3}{*}{ Animal case (200) } & \multicolumn{4}{|c|}{ Horses (200) } & \multicolumn{4}{|c|}{ Donkeys (200) } \\
\hline & \multicolumn{8}{|c|}{ Microorganisms } \\
\hline & \multicolumn{2}{|c|}{ Strept. equi } & \multicolumn{2}{|c|}{ Other species } & \multicolumn{2}{|c|}{ Strept. equi } & \multicolumn{2}{|c|}{ Other species } \\
\hline Apparently healthy (200) & 27 & 51.92 & 73 & 34.21 & 12 & 37.5 & 13 & 30.23 \\
\hline Diseased ones (200) & 25 & 48.08 & 25 & 65.79 & 20 & 62.5 & 30 & 59.77 \\
\hline Total (400) & 52 & 100 & 38 & 100 & 32 & 100 & 43 & 100 \\
\hline
\end{tabular}

The bacteriological examination of (400) samples collected from animals revealed that the rate of isolation of Strept. equi sub. sp. was 39 (46.43\%) and $45(53.57 \%)$, apparently and diseased animals, respectively as shown in Table (5).

Table (6) illustrated that the rate of Strept. equi sub sp. equi was 27 $(51.92 \%)$ and $12(37.5 \%)$ in horses and donkeys respectively while its rate in diseased ones was $25(48.08 \%)$ and $20(62.5 \%)$ of horses and donkey respectively.

Morphological identification of isolates showed large mucoid with large clear beta-haemolytic zone around it of blood agar microscopically, they were gram's positive round or coccus in shape arranged singly to in pair, biochemical activities of Strept. equi sub species equi revealed catalase and oxidase test were negative and fermentation to salicin. 
With regard to the results of pathogenicity test in white mice, by inoculated S/C with suspected colonies of Strept. equi sub sp. equi (24 hours old culture). These mices died within 7 days, its body weight was reduced with a subsequently developed septicemia. Then the test strain was reisolated and was identified.

Table (7): The rate of Streptococcus equi from apparently healthy and diseased horses and donkeys No. Strept equi (184).

\begin{tabular}{||c||c||c|c||c|c||c|c||}
\hline \multirow{2}{*}{ Type of sample swab } & \multirow{2}{*}{ Sate of animals } & \multicolumn{2}{|c|}{ Horses } & \multicolumn{2}{|c||}{ Donkeys } & \multicolumn{2}{|c|}{ Total } \\
\cline { 3 - 8 } & & No. & $\%$ & No. & $\%$ & No. & $\%$ \\
\hline \hline \multirow{2}{*}{ Abscess } & \multirow{2}{*}{$\begin{array}{c}\text { Diseased animals } \\
\text { Deep nose }\end{array}$} & 10 & 18.5 & 7 & 21.88 & 17 & 20.24 \\
Rectum & & 5 & 9.25 & 3 & 9.38 & 8 & 9.52 \\
\hline \multirow{2}{*}{ Deep nose } & Apparently healthy & 22 & 40.74 & 10 & 31.25 & 32 & 38.10 \\
Rectum & animals & 5 & 9.25 & 2 & 6.25 & 7 & 8.33 \\
\hline \hline
\end{tabular}

Table (7) revealed that the rate of Strept. equi sub. sp. equi according to site of isolation was 10 (18.5\%) from abscess, 10 (18.5\%) from deep nose and 5 (9.25\%) from rectum of diseased horses while in diseased donkey, it was 7 (21.88\%) from abscess, $10(31.25 \%)$ from deep nose and $3(9.38 \%)$ from deep nose and 3 (9.38\%) from rectum. Also, this rate among, than apparently healthy animal was 22 (40.74\%) from deep nose and 5 (9.25\%) from rectum in horses and in donkeys, it was 10 (32.25\%) and 2 $(6.25 \%)$ from deep nose and rectum respectively. 
Table (8): The results of sensitivity test to Strept. equi sub. sp. equi which isolated from horses and donkeys.

\begin{tabular}{|l||c|c|c||}
\hline \multirow{2}{*}{ Antimicrobial agent } & \multicolumn{3}{|c|}{ Total number of isolated strains (84) } \\
\cline { 2 - 4 } & No of sensitive strains & No of resistant strains & Activity *\% \\
\hline \hline Ampicillin & 80 & 4 & 95.24 \\
Tetracyclin & 70 & 14 & 83.33 \\
Gentamycin & 70 & 14 & 83.33 \\
Erythromycin & 30 & 54 & 35.71 \\
Kanamycin & 35 & 49 & 41.67 \\
Lincomycin & 30 & 54 & 35.71 \\
Strptomycin & 70 & 14 & 83.33 \\
\hline
\end{tabular}

$*$ The activity $\%=\frac{\text { Number of sensitve isolates }}{\text { Total nubmer of isolates }} \times \mathbf{1 0 0}$

Table (8) was shown that the activity sensitivity \% of all isolated Strept. equi sub. sp. equi was $95.24 \%$ (Ampicillin), $83.33 \%$ (for tetracycin, gentamycin and streptomycin) and it was lower activity sensitive for kanamycin, erythromycin and lincomycin.

\section{DISCUSSION}

The clinical manifestation of the infected horses and donkeys examined in this study were fever, anorexia and sign of depression. The most frequent signs were unilatered swelling of the throat region, respiratory dyspnoea, purulent discharge and these symptoms agreed with those reported by Osman, R.M. (1979), Goland et al. (1995), Hashikawa et al. (2004), and Goethining et al. (2005).

Streptococcus is an important pathogenic bacteria causing serious disease called strangles. The animals suffer from economic border associated with disease which necessitates effective treatment by current antibiotics (Harrington et al., 2002). 
The most more isolated pathogenic bacteria was Strept. equi sub. sp. equi, this result agreed with the results reported by Bradley et al. (1991) and Babter et al. (2000).

This study revealed that the total incidence bacterial isolate was 52 $(26 \%)$ in horses and $32(16 \%)$ in donkeys, these results are similar with results obtained by Dawalt, M.A. (2001).

The incidence of Strept. equi sub. sp. was 25 (12.5\%) and 20 (10\%) in diseased horses and donkey respectively and also it was 27 (13.5\%) and $12(6 \%)$ in an apparently healthy horses and donkeys respectively, these percentage approach to results obtained by Azza and Amany (2006).

These research results cleared that the rate of Strept. equi sub. sp. equi was 17 (20.24\%) from abscess, 20 (23.81\%) from deep nose and 8 $(9.52 \%)$ in diseased, horses and donkey while, in apparently horses and donkeys, it was 32 (38\%) from deep nose and 7(8.33\%) from rectum. These results were higher than the results obtained by Osman (1979).

The pathogenicity test performed fro reisolate Strept. equi sub. $s p$. equi strains by using the albino mice as model realed in body weight with a sign of septicemic and the mice within 7 days. The picture agree with the work was done by Chanter et al. (1995).

From study was appeared that the rate of other streptococci species was similar or nearly to rate be obtained fro Strept. equi sub. sp. equi which isolated from horses and donkeys (apparently health and/or diseased ones). This point cleared that other Streptococci sp. act as addition stress factor on these equine animals, beside that they exposed to hard work. 
From this research, it was found that most of Strept. equi sub. sp. equi more sensitive to ampicillin, streptomycin, tetracycline and gentamycin and less sensitive to erythromycin, kanamycin and lincomycin, this true are shured by the results recoded by Abou Zeid et al. (1989), Salmon et al.(1995)and Radial(1997). These antibiotic were recommended in treating the clinical cases.

\section{REFERENCES}

- Abou-Zeid, A.A.; Hatem, M.E. and Husein, N. (1989). Clinical eizootologial and bacteriological investigation on strangles in Arabian horses in Egypt. Egypt. Vet. Med. Ass. 49(4): 1045-1062.

- Anzil, T.; Nokanishi, A. and Inouc, T. (1997). Isolation of S. equi subsp. equi from through bred horses. J. Ve.t Med. Sci. 50, 10311039.

- Azza, N. Farag and Amany N. Dapoh (2006). Bacteriological studies of $S$. equi in Equine J. Egypt. Vet. M., Assoc. 66, No. 4,. 147-165.

- Bailey, W.R. and Scott, E.G. (1974). VEterianry medicine of $4^{\text {th }}$ edition. The English language-Boack, Society and Ballerre Tindal.

- Balter, S.; Benin, A.; Pinto, S.W.; Teixeira, L.M.; Alvim, G.G.; Luna, E. Jackson, D.; LaClaire, L. El-Liott, J.; Fackiam, K. and Schuchat, A. (2000). Epidemic nephritis in Nova serrana. Brazil lancet, 20: 355 (9217): 1776-1780.

- Bradley, S.F.; Gordon, J.J.; BAumgurine, D.D.; Marasco, W.A. and Kauffman (1991). Group C streptococcal bactermia analysis of 88 cases. Clin. Infect. Dis. 1992 Feb. 14(2): 616-617. Rev. Infect. Dis. 13(5): 1029-1030. 
- Cayeux,P.and Panijel,J.(1965). Studies on the virulence of streptococcus cyorens group A. Animal Inst. Pasteur, Paris, 105, 623-631.

- Chanter, N.; Smith, K.C. and Mumford, J.A. (1995). Equine strangles modeled in mice Vet. Microbiol. 43(2-3): 209-218.

- Cruichshank, R.; Dugiua, J.P.; Masmion,B.P. and Swain, R.H.A. (1975). Medical microbiology. The practice of Medical microbiology. $12^{\text {th }}$ Ed., Vol. 11 Churchill. Living Stone. Edinburgh, London and New York.

- Dawlat, M. Amin, Nareman, A. Rahmy, Seleim, R.S. and El-Nagar. M. (2001). Bacteriological and pathoglogical studies on Streptococcus equi infection Arabian Horses. Egypt. Vet. Med. Assoc. 61, No. 6A: 151-168.

- Farag, A.N. and Dapgh, A.M. (2006). Bacteriological studies of S. equi in equine. J. Egyptian Vet. M. Association. Vol. 66, NO. 4, p. 147-165.

- Farrow, J.A.R. and Collins, M.D. (1984). Taxonomic studies on streptococci group C.C. and possibility related daxa. System. App. Microbiol. 5, T. 483-494.

- Finegold, S.M. and Martin, W.T. (1982). Diagnostic microbiology $6^{\text {th }}$ Ed. C.V Mosby Co. St. Louis Toronto London.

- Galland, L.C.; Hodgson, D.R.; Davis, R.E.; Rawlinson, R.J.; Collins, M.B.; McClintoxk, S.A. and Hutchinsm, D.R. (1995). Reuopharyngeal, lymh node infection in horses 46 cases. (19771992).

- Goethining, L.S.; Van Manen, C.and Solet Van Olduitenborgh and Oosterbaan, M.M. (2005). Neurological syndromes among horses in the Netherlands A 5 year tetrospective survey (1999-2004). 
- Gronback, L.M.; Angen, O.; Vigre H. and Olsen, S. (2006). Evaluation of anested PCR tested and bacterial culture swabs from the nasal passagages and from abscesses in relation diagnosis of Streptococcus equi infection (strangles) equine. Vet. J. 38(1): 59-63.

- Harrainoton, D.J. Sutcliffe, I.C. and Chanter, N. (2002). The molecular basis of Streptococcus equi infection and diseases Microbes. Infect., 4(9) p. 501-510.

- Hashikawa, S.; Linuma, Y.; Furushita, M. Ohkura, T.; Nada, T.; Torii, K.; Hasegawa, T. and Ohta, M. (2004). Characterization of group C and $\mathrm{G}$ streptococcal strains that cause streptococcal toxic shock syndrome. J. Clin. Microbil., 42(1): 186-192.

- Osman, R.M. (1979). Studies on streptococci in equines Master of veterinary Science, Microbiology.

- Raidal, S.Z. (1997). Equine pleuropneumonia Br. Vet. 151, 233-262.

- Roukaya Mohamed Osman(1979). Studies on streptococci in Equines Master of Veterinary Department. of Microbiology Faculty of Vet. Med. Cairo University.

- Salmon, S.A.; Watts, L.J. Case, C.A.; Hoffman, J.J.; Wegener, H.C.and Yanceyh, R.J. (1995). Comparison of Mics of cefrofur and other antimicrobial agent against bacterial pathogens of swine from the United States, Canada and Denmark,. J. Clin. Microbil. 33(9): 2319-2344.

- Soltys, M.A. (1963). Bacteria and fungi pathogenic to man and animals. $1^{\text {st }}$ Ed. Bailiers Tindal and Xoc. London.

- Spoormakers, T.J.; Ensink, J.M.; Goehring, L.S.; Romeman, J.P.; Er. Branke, F.; Van der. Vlugt-Meijer, R.H. and Van den Belt, A.J. (2003). Brain abscesses as a metastattic manifestation of strangles. Symptomatology and the use of magnetic response maging as a disagnostic and equine. Vet. J. 35(2): 118-120. 


\section{عزل وتصنيف ميكروب استربتوكوكس إكواى تحت نوع إكواى المسبب \\ لمرض خناق الخيل من حيوانات الفصيلة الخيلية}

\section{طلعت حامد ملاحت شعيشع بلير

$$
\text { باحث أول ــ معمل بيطري كفر الثيخ / معهُ بحوث صحة الحيوان ـ الدقى }
$$

قد جمعت 400 عينة من 200 رأس خيل (تشمل 100 رأس سليمة ظاهريا و 100 رأس مصابة). هذه العينات نم تجميعها من خراريج الغدد الليمفاوية والأنف وفتحة المستقيم من حيو انات الفصيلة الخيلية نسبة الميكروب ..... اكواى تحت نوع إكواى كانت 52 (26\%) من 200 رأس حصان و 32 (16\%) من رأس حمار.

نسبة هذا الميكروب كانت 25 (12.5\%) و 20 (10\%) بالنسبة للحيو انات المصابة من الخيول و الحمير على التو الي بينما النسبة كانت فى الحيو انات السليمة ظاهريا هى 27 (13.5\%) و 12(\%) بالنسبة للخيول و الحمير على النو الي.

معدل تو اجد ميكروب السيمى إكواى تحت نوع إكو اى كانت 27 (51.92\%) و 12 (37.5

\%) بالنسبة للحيو انات السليمة ظاهريا من الخيول والحمير على التوالى بينما كانت نسبتة فى لئ الحيو انات المريضة هى 25 (48.8\%و 20 (62.5\%) من الخيول و الحمير على التو الي. جميع العزلات بنسبة كبيرة كانت حساسة لكل من الأمبسيلين (95.24\%) و التنز اسيكلين (83.33\%) و استربنومايسين (83.33\%) و جنتاميسين (83.33\%) و على الجانب الأخر كانت أقل

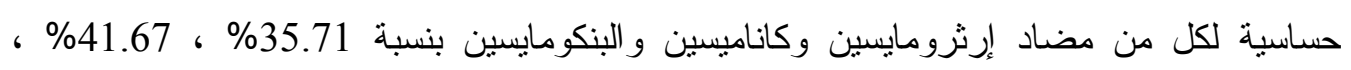
35.71

هذه الدراسة أظهرت أن الميكروب السبحى أكواى تحت نوع اكواى يملك القدرة على الانتشار والثأثثر على الخيول والحمير عندما تتعرض الى مؤثرات خارجية مثل العمل الثشاق وسوء التغذية. 